\title{
Penerapan Metode Moora Dalam Menentukan Parfume Terbaik Berdasarkan Kepribadian
}

\author{
Halimatusakdiah Pohan ${ }^{1}$, Dwita Elisa Sinaga ${ }^{2}$ \\ Sistem Informasi, STIKOM Tunas Bangsa \\ Jl. Sudirman Proklamas, Siantar Barat \\ Kota Pematangsiantar, Sumatera Utara, 21143 \\ halimapohan104@gmail.com ${ }^{1}$,dwitaelisa01sinaga@gmail.com ${ }^{2}$
}

\begin{abstract}
Parfume is one of the distinctive scented liquids that people use to eliminate body odor, in the use of parfume, people tend to have different types of parfume according to their personality type. Based on many personalities that exist in society, the writer uses one personality Sangunis where someone who has this personality is cheerful, friendly, warm and friendly but prefers a pungent aroma because usually someone with a Sangunins personality likes to socialize wherever they are. In this article the author uses one of the SPK methods MOORA, which has the advantage of being simple, stable and easy to implement, so it is hoped that the Moora method can help someone in making a perfume selection decision.
\end{abstract}

Keywords: MOORA, SPK, Perfume, Sanguinis,Pematangsiantar

\section{Abstrak}

Parfum adalah salah satu cairan yang beraroma khas yang digunakan masyarakat untuk menghilangkan bau badan, dalam penggunaan parfum masyarakat cenderung memiliki jenis parfum yang berbeda-beda sesuai dengan tipe kepribadiannya. Berdasarkan banyaknya kepribadian yang ada di masyarakat, penulis menggunakan salah satu kepribadian yaitu Sanguinis, dimana seseorang yang memiliki kepribadian ini bersifat ceria, ramah, hangat dan bersahabat tetapi lebih menyukai aroma yang tidak menyengat karena biasanya seseorang yang berkepribadian sanguinis suka bergaul dimana pun mereka berada. Dalam artikel kali ini penulis menggunakan salah satu metode dari SPK yaitu MOORA ,yang memiliki keunggulanyaitu sederhana, stabil dan mudah di implementasikan, sehingga diharapkan metode Moora ini dapat membantu seseorang dalam pengambilan keputusan pemilihan parfum.

Kata kunci : MOORA, SPK, Parfum, Sanguinis, Pematangsiantar.

\section{Pendahuluan}

Parfum adalah cairan wewangian yang dihasilkan dari ekstrak tumbuh-tunbuh atau hewan yang digunakan untuk memberikan aroma yang wangi. Pada saat ini penampilan merupakan suatu hal yang sangat penting di berbagai kalangan masyarakat, salah satunya penggunaan parfum. Menggunakan parfum bagi seseorang dapat meningkatkan kepercayaan diri untuk tampil di muka umum. Parfum juga sebagai aroma khas seseorang kala berada di antara kerabat, sahabat, orang terdekat, atau pun lingkungan masyarakat. Perkembangan parfum yang meningkat dan beragam jenisnya membuat sesorang kesulitan untuk menentukan jenis parfum yang akan digunakan sesuai dengan kepribadiannya. Kepribadian merupakan karakteristik, gaya atau sifat-sifat yang menjadi ciri khas dari diri seseorang. Untuk menentukan tipe kepribadian mendasar seseorang salah satunya bisa melalui aroma parfum yang disukai. Tipe kepribadian mendasar sendiri dibagi menjadi 4 yaitu Koleris, Plegamtis, Melankolis, dan Sanguinis.

Pada artikel ini kami akan membahas tentang pemilihan parfum berdasarkan kepribadian Sanguinis dimana kepribadian ini dijuluki kepribadian yang populer 
memiliki kecenderungan akan disenangi banyak orang, karena kepribadian mereka yang spontan, lincah, periang, dan karisma mereka yang menarik orang kepada mereka [1]. Berdasarkan kepribadian ini sanguinis lebih cenderung menyukai aroma parfum yang tidak menyengat. Dengan melakukan wawancara kepada beberapa narasumber yang berkepribadian sanguinis di kota Pematangsiantar kami mendapatkan 4 merk parfum yang lebih diminati beberapa narasumber yaitu: Vitalis, Eskulin, Posh dan Marina.

\section{Metodologi Penelitian}

\subsection{Sistem Pendukung Keputusan}

Konsep Sistem Pendukung Keputusan (SPK) atau Decision Support System (DSS) yang pertama kali di ungkapkan pada awal tahun 1970-an oleh Michael S. Scott Morton dengan istlah Management Decision Systems [2]. Sistem ini merupakan sistem yang terkomputerisasi yang digunakan untuk membantu memecahkan suatu masalah dengan memanfaatkan data dan kasus tertentu dalam pengambilan keputusan.

Menurut Kosasi dan Kusrini (2007), adapun ciri-ciri sebuah SPK seperti yang dirumuskan oleh Alters Keen adalah sebagai berikut:

a) SPK ditujukan untuk membantu pengambilan keputusan-keputusan yang kurang terstruktur dan umumnya dihadapi oleh para manajer yang berada di tingkat puncak.

b) SPK merupakan gabungan antara kumpulan model kualitatif dan kumpulan data.

c) SPK memiliki fasilitas interaktif yang dapat mempermudah hubungan antara manusia dengan komputer.

d) SPK bersifat luwes dan dapat menyesuaikan dengan perubahan-perubahan yang terjadi[3].

\subsection{Metode Multi-Objective Optimization On The Basis Of Ratio Analysis (MOORA)}

Metode MOORA, pertama kali diperkenalkan oleh Brauers (2004) adalah suatu teknik optimasi multiobjective yang dapat berhasil diterapkan untuk memecahkan berbagai jenis masalah pengambilan keputusan yang kompleks dalam lingkungan manufaktur [4].

Langkah - langkah penyelesain masalah menggunakan metode Moora :

1. Pembentukan Matriks

$$
\mathrm{X}_{\mathrm{ij}}=\left[\begin{array}{cccc}
x_{11} & x_{12} & \ldots & x_{1 n} \\
x_{21} & x_{22} & \ldots & x_{2 n} \\
\vdots & \vdots & \vdots & \vdots \\
x_{m 1} & x_{m 2} & \ldots & x_{m n}
\end{array}\right]
$$

$\mathrm{x}$ adalah nilai kriteria masing-masing kriteria yang direpresentasikan sebagai matriks.

2. Menetukan Matriks Normalisasi

$$
\mathrm{x}_{\mathrm{ij}}=\frac{x i j}{\sqrt{\sum_{j}^{m}=1 x_{i j}^{2}}}
$$

Rasio Xij menunjukan ukuran ke i dari alternatif pada kriteria ke $\mathrm{j}$, m menunjukan banyaknya jumlah alternatif dan $n$ menunjukan jumlah kriteria.

3. Menentukan Matriks Normalisasi terbobot

$$
\begin{gathered}
\mathrm{y}_{\mathrm{i}=} \sum_{j=1}^{g} x_{i j}-\sum_{j=g+1}^{n} x_{i j} \\
\mathrm{y}_{\mathrm{i}}=\sum_{j=1}^{g} w_{j} x_{i j}-\sum_{j=g+1}^{n} w_{j} x_{i j}(j=1,2, \ldots, n)
\end{gathered}
$$

Dimana $\mathrm{Wj}$ adalah bobot dari kriteria ke $-\mathrm{j}$.

4. Menentukan Nilai Preferensi

Alternatif terbaik memiliki nilai yi tertinggi, sedangkan alternatif terburuk memiliki nilai yi terendah [5]. 


\section{Hasil dan Pembahasan}

Dengan melakukan wawancara kepada beberapa narasumber yang berkepribadian sanguinis di kota Pematangsiantar penulis mendapatkan 4 kriteria parfum yang akan dijadikan sebagai rekomendasi pemilihan prafum terbaik. Berikut tahapan dari perhitungan metode MOORA dalam menentukan rekomendasi parfum terbaik yaitu :

a) Menentukan tabel kriteria

Kriteria yang digunakan dalam penilaian parfum terbaik yang telah ditentukan menjadi 4 kriteria yang akan ditunjukkan pada tabel 1 .

Tabel 1. Kriteria

\begin{tabular}{cccc}
\hline Kriteria & Keterangan & Bobot & Jenis \\
\hline C1 & Harga & 0.2 & Cost \\
C2 & Kualitas & 0.3 & Benefit \\
C3 & Ketersediaan barang & 0.25 & Benefit \\
C4 & Kemasan & 0.25 & Benefit \\
\hline
\end{tabular}

b) Menentukan tabel Alternatif

Adapun alternatif yang digunkan sebagai acuan dalam pengambilan keputusan yang akan ditunjukkan pada tabel 2 .

Tabel 2. Alternatif

\begin{tabular}{cccccc}
\hline Alternatif & Keterangan & C1 & C2 & C3 & C4 \\
\hline Vitalis & A1 & 0.76945 & 0.68889 & 0.8 & 0.72222 \\
Eskulin & A2 & 0.76429 & 0.68571 & 0.8 & 0.77625 \\
Posh & A3 & 0.65 & 0.58333 & 0.825 & 0.74167 \\
Marina & A4 & 0.75 & 0.5 & 0.8 & 0.7 \\
\hline
\end{tabular}

Berikut ini merupakan Langkah - langkah penyelesain masalah menggunakan metode Moora yaitu :

1) Pembentukan Matriks

Berdasarkan data yang diperoleh dapat dibentuk sebuah matriks $\mathrm{x}_{\mathrm{ij}}$ yaitu:

$$
\mathrm{X}_{\mathrm{ij}}=\left[\begin{array}{cccc}
0.76945 & 0.68889 & 0.8 & 0.72222 \\
0.76429 & 0.68571 & 0.8 & 0.77625 \\
0.65 & 0.5833 & 0.825 & 0.74167 \\
0.75 & 0.5 & 0.8 & 0.7
\end{array}\right]
$$

2) Menetukan Matriks Normalisasi

Normalisasi matriks $\mathrm{x}$ untuk menghitung nilai masing-masing matriks yaitu

$$
\begin{aligned}
\mathrm{C} 1 & =\sqrt{0.76945^{2}+0.76429^{2}+0.65^{2}+0.75^{2}} \\
& =\sqrt{0.592046+0.584132+0.4225+0.5625} \\
& =\sqrt{2.16118} \\
& =1.47009 \\
\mathrm{~A} 11 & =0.76945 / 1.47009=0.5234 \\
\mathrm{~A} 21 & =0.76429 / 1.47009=0.51989 \\
\mathrm{~A} 31 & =0.65 / 1.47009=0.44215 \\
\mathrm{~A} 41 & =0.75 / 1.47009=0.51017 \\
\mathrm{C} 2 & =\sqrt{0.68889^{2}+0.68571^{2}+0.58333^{2}+0.5^{2}} \\
& =\sqrt{0.47457+0.4702+0.34027+0.25} \\
& =\sqrt{1.53504} \\
& =1.23897 \\
\text { A12 } & =0.68889 / 1.23897=0.55602 \\
\mathrm{~A} 22 & =0.68571 / 1.23897=0.55345 \\
\text { A32 } & =0.58333 / 1.23897=0.47082 \\
\text { A42 } & =0.5 / 1.23897=0.40356
\end{aligned}
$$




$$
\begin{aligned}
\mathrm{C} 3 & =\sqrt{0.8^{2}+0.8^{2}+0.825^{2}+0.8^{2}} \\
& =\sqrt{0.64+0.64+0.68063+0.64} \\
& =\sqrt{2.60063} \\
& =1.61265 \\
\mathrm{~A} 13 & =0.8 / 1.61265=0.49608 \\
\mathrm{~A} 23 & =0.8 / 1.61265=0.49608 \\
\mathrm{~A} 33 & =0.825 / 1.61265=0.51158 \\
\mathrm{~A} 43 & =0.8 / 1.61265=0.49608 \\
\mathrm{C} 4 & =\sqrt{0.72222^{2}+0.77625^{2}+0.74167^{2}+0.7^{2}} \\
& =\sqrt{0.52161+0.60256+0.55007+0.49} \\
& =\sqrt{2.16424} \\
& =1.47114 \\
\text { A14 } & =0.72222 / 1.47114=0.49093 \\
\text { A24 } & =0.77625 / 1.47114=0.52765 \\
\text { A34 } & =0.74167 / 1.47114=0.50415 \\
\text { A44 } & =0.7 / 1.47114=0.47582
\end{aligned}
$$

Maka hasil matriks normalisasinya yaitu :

$$
\mathrm{Xij}=\left[\begin{array}{cccc}
0.5234 & 0.55602 & 0.49608 & 0.49093 \\
0.51989 & 0.55345 & 0.49608 & 0.52765 \\
0.44215 & 0.47082 & 0.51158 & 0.50415 \\
0.51017 & 0.40356 & 0.49608 & 0.47582
\end{array}\right]
$$

3) Menentukan Matriks Normalisasi terbobot

Perhitungan untuk mencari matriks normalisasi terbobot yaitu :

$$
\mathrm{Xij}=\left[\begin{array}{cccc}
0.5234(0.2) & 0.55602(0.3) & 0.49608(0.25) & 0.49093(0.25) \\
0.51989(0.2) & 0.55345(0.3) & 0.49608(0.25) & 0.52765(0.25) \\
0.44215(0.2) & 0.47082(0.3) & 0.51158(0.25) & 0.50415(0.25) \\
0.51017(0.2) & 0.40356(0.3) & 0.49608(0.25) & 0.47582(0.25)
\end{array}\right]
$$

Dan hasil perhitungannya adalah berikut ini :

$$
\mathrm{Xij}=\left[\begin{array}{cccc}
0.10468 & 0.16681 & 0.12402 & 1.96371 \\
0.10398 & 0.16604 & 0.12402 & 0.40959 \\
0.08843 & 0.14125 & 0.1279 & 0.12604 \\
0.10203 & 0.12107 & 0.12402 & 0.11896
\end{array}\right]
$$

4) Menentukan Nilai Preferensi

Perhitungan untuk menentukan nilai preferensi alternatif $y_{i}$ dapat dilihat dari tabel 3 yaitu

Tabel 3. Hasil $y_{i}$

\begin{tabular}{cccc}
\hline Alternatif & Max $(\mathbf{C 2}+\mathbf{C 3}+\mathbf{C 4})$ & Min $(\mathbf{C 1})$ & $\mathbf{Y i}=\mathbf{m a x}-\mathbf{m i n}$ \\
\hline A1 & 2.254539397 & 0.10468 & 2.149859397 \\
A2 & 0.69964634 & 0.10398 & 0.59566634 \\
A3 & 0.395177613 & 0.08843 & 0.306747613 \\
A4 & 0.364044478 & 0.10203 & 0.262014478 \\
\hline
\end{tabular}

Dan hasil dari perhitungan metode MOORA yaitu

Tabel 4. Hasil Ranking

\begin{tabular}{ccc}
\hline Alternatif & Hasil & Peringkat \\
\hline A1 & 2.149859397 & 1 \\
A2 & 0.59566634 & 2 \\
A3 & 0.306747613 & 3 \\
A4 & 0.262014478 & 4 \\
\hline
\end{tabular}




\section{Kesimpulan}

Berdasarkan penelitian yang telah dilakukan oleh penulis maka dapat disimpulkan bahwa metode Multi-Objective Optimization On The Basis Of Ratio Analysis (MOORA) merupakan suatu metode penentuan prioritas yang dapat dikatakan cukup sederhana. Dimana pada artikel ini kami memperoleh bahwa masyarakat dengan kepribadian Sanguinis lebih dominan menggunakan parfum dengan Merk Vitalis. Perangkingan ini dihasilkan dengan keputusan yang efektif dan objektif berdasarkan data yang diperoleh dari hasil kuisioner dan wawancara dengan masyarakat di kota Pematangsiantar.

\section{Daftar Pustaka}

[1] H. Damayanti and S. Lestari, "Analisis Penyesuaian Diri," 2008.

[2] K. J. Hondro, Y. Franky, and D. Batubara, Hamonangan, "Sistem Pendukung Keputusan Pemilihan Duta Kampus Terbaik Mengunakan Multi Objective Optimization on The Basis of Ratio Analysis (MOORA)," pp. 501-506, 2018.

[3] D. L. Kurniasih, "Sistem Pendukung Keputusan Pemilihan Laptop Dengan Metode Topsis Diterbitkan Oleh : STMIK Budi Darma Medan Diterbitkan Oleh : STMIK Budi Darma Medan," vol. III, no. 2, pp. 6-13, 2013.

[4] S. Al-hafiz, Mesran, "Sistem Pendukung Keputusan Penentukan Kredit Pemilikan Rumah Menerapkan Multi-Objective Optimization On The Basis Of Ratio Analysis (MOORA)," vol. I, no. 1, pp. 306-309, 2017.

[5] A. Septi, R. Anggreani, H. Rotua, B. Hutapea, and M. Syahrizal, "Sistem Pendukung Keputusan Penentuan Handphone Bekas Terbaik Menggunakan Metode Multi-Objective Optimization on The Basis of Ratio Analysis (MOORA)," vol. 5, no. 1, pp. 61-65, 2018. 